\title{
In vitro evaluation of the antiviral activity of extracts from the lichen Parmelia perlata (L.) Ach. against three RNA viruses
}

\author{
Charles O. Esimone, ${ }^{1}$ Kenneth C. Ofokansi, ${ }^{1}$ Michael U. Adikwu, ${ }^{1}$ Emmanuel C. Ibezim, ${ }^{1}$ \\ Dominic O. Abonyi, ${ }^{1}$ Georgina N. Odaibo, ${ }^{2}$ David O. Olaleye. ${ }^{2}$ \\ ${ }^{1}$ Division of Pharmaceutical Microbiology, Department of Pharmaceutics, Faculty of Pharmaceutical Sciences, University of \\ Nigeria, Nsukka, Nigeria; ${ }^{2}$ Department of Virology, University College Hospital, University of Ibadan, Nigeria.
}

\begin{abstract}
Background: Substances extracted from lichens have previously been reported to possess antimicrobial activities against various groups of bacteria, fungi and viruses. Due to the high abundance of Parmelia perlata in the Eastern parts of Nigeria, we decided to explore whether it possesses antiviral activity against some common animal and human viruses.

Methodology: The dried and powdered lichen was extracted with acetone, water and $4 \%$ ( $/ \mathrm{v}$ ) $\mathrm{NaOH}$ (to yield a crude polysaccharide fraction) using standard methods. The cytotoxicity of the extracts was investigated on HEP-2, Vero and $L_{20}$ cell lines. The antiviral properties were determined against yellow fever, poliomyelitis and infectious bursal disease virus of chickens using the end-point cytopathic effect assay. Phytochemical evaluations of the extracts were also carried out.

Results: Phytochemical tests showed the presence of flavonoids, saponins, tannins, glycosides, steroidal aglycone, carbohydrates and also the presence, in trace amounts, of some oligodynamic elements. Cytotoxicity tests revealed that while $\mathrm{L}_{20}$ was susceptible to the extracts at a concentration of $50 \mu \mathrm{g} / \mathrm{ml}$, the extracts were generally toxic to the cell lines at concentrations above $500 \mu \mathrm{g} / \mathrm{ml}$. The order of sensitivity of the cell lines was $\mathrm{L}_{20}>\mathrm{HEP}-2>$ Vero. The water and acetone extracts showed no activity against the viruses when tested at concentrations below the cytotoxic level while the crude polysaccharide fraction showed activity against yellow fever virus with an $\mathrm{IC}_{50}$ of $15 \mu \mathrm{g} / \mathrm{ml}$. The time of addition of the test extracts to the infected cells did not have significant effect on cytopathic effect inhibition.

Conclusions: The results showed that the crude polysaccharide fraction from Parmelia perlata possesses specific antiviral activity against yellow fever virus. It is postulated that a major mechanism of inhibition of yellow fever infection by the crude polysaccharide fraction of the lichen could be by attack on the viral envelope.

Key Words: Parmelia perlata, Lichen, Yellow fever, infectious bursal disease virus, Polio virus, Cytotoxic activity, Antiviral activity.
\end{abstract}

J Infect Developing Countries 2007; 1(3):315-320.

Received 15 October 2007 - Accepted 14 November 2007.

Copyright $@ 2007$ Esimone et al. This is an open access article distributed under the Creative Commons Attribution License, which permits unrestricted use, distribution, and reproduction in any medium, provided the original work is properly cited.

\section{Introduction}

There are fewer substances available for the treatment of viral infections when compared with the large amount of available antibiotics for the treatment of bacterial infections. At the same time, the frequencies of viral resistance to the relatively few antiviral drugs are increasing [1]. This, coupled with the challenges posed by the human immunodeficiency virus (HIV) and its related diseases, has renewed interest in the search for a new antiviral agent in recent times [2]. However, progress in the development of useful new antivirals has been painstakingly slow. Hence the increasingly urgent need to find effective therapeutics for viral infections justifies a broad and accelerated search for antiviral.

Plants and plant products present some hope to scientists, serving as an alternative avenue to discovery from the current mainstream approach of attempting to design narrow spectrum drugs for specific molecular targets [2-4]. While numerous reports exist on the antimicrobial effect of lichens against various groups of bacteria and fungi [5-8], only very few reports exist on the antiviral activity of these plants/products [9]. Recently, we have demonstrated that extracts from the lichen Ramalina farinacea inhibited the growth of two different viral classes (HIV-1 and Adenoviruses) [10]. 
In this report, the results of the determination of antiviral activity of crude extracts of the lichen Parmelia perlata are presented. Parmelia perlata grows on trees and rocks especially in the West of Britain and also in the tropics [11]. It forms large light-grey patches with rounded lobes, which often have black hairs at the edges. Clusters of greyish white powdery reproductive structures (soredia) grow on the upturned tips of some of the lobes and large spore-producing apothecia with dark-brown discs and prominent margins sometimes develop in the centre. In recent times, there has been a renewed interest in the search for antivirals from the plant kingdom [4,12]. This interest provided the necessary stimulus to undertake this present study, which aims to evaluate the in vitro cytotoxic and antiviral properties of extracts from the lichen $P$. perlata.

\section{Materials and Methods}

Collection of the plant material

The lichen was collected from oil bean tree (Pentaclethra macrophylla Benth) trunks in Umuowulla forest, Ogbozalla Opi, Nsukka Local Government Area of Enugu State, Nigeria. Mr. J.M.C. Ekekwe of the botanical garden, University of Nigeria, Nsukka, made botanical identification and Voucher specimen has been deposited in the University Herbarium.

\section{Cell lines and viruses}

The continuous cell lines used-laryngeal epidemoid carcinoma (Hep2), monkey kidney (Vero) and $\mathrm{L}_{20}$ cells-were propagated using RPMI (Rolswell Park Memorial Institute ) medium (Gibco, Germany) supplemented with $2 \%$ heat-inactivated fetal calf serum (FCS), $100 \mathrm{U} / \mathrm{ml}$ penicillin, and 100 $\mu \mathrm{g} / \mathrm{ml}$ streptomycin. Cells were obtained from the Department of Virology, University College Hospital, Ibadan, Nigeria.

Stock culture of poliomyelitis virus and infectious bursal disease virus (IBDV) of chickens were obtained from the virology laboratory, University College Hospital (UCH) Ibadan, Nigeria. Yellow fever virus was obtained through a passage of yellow fever vaccine (log No. 5708, STAMARIL PASTEUR) kindly supplied by the Public Health Department (National Programme on Immunization Unit), Ministry of Health, Enugu State, Nigeria.

\section{Extraction}

Sufficient samples of the lichen were ovendried for 24 hours at $40^{\circ} \mathrm{C}$ and ground to a powdered form using a hand mill. To obtain the crude polysaccharide fraction (CPF), a $1 \mathrm{~g}$ sample of the powder was weighed into a conical flask containing $20 \mathrm{ml}$ of $40 \% \mathrm{w} / \mathrm{v}$ sodium hydroxide solution and $1 \% \mathrm{w} / \mathrm{v}$ sodium borohydride solution. These were shaken for 24 hours in a Gallenkamp orbital shaker at $150 \mathrm{rpm}$ at $28^{\circ} \mathrm{C}$. The homogenate was neutralized using glacial acetic acid, centrifuged at $300 \mathrm{rpm}$ for 5 minutes at $28^{\circ} \mathrm{C}$ and the supernatant collected. The extract was precipitated and partially purified with $98 \%$ ethanol.

For the water extract (WTE), a $200 \mathrm{~g}$ sample of the powdered lichen was weighed into a $1,000 \mathrm{ml}$ capacity conical flask containing $400 \mathrm{ml}$ of distilled water and extracted for 48 hours in an oven at $40^{\circ} \mathrm{C}$. This was then filtered with a Whatman filter paper and the filtrate evaporated to dryness in an oven at $55^{\circ} \mathrm{C}$. A similar procedure to that of the water extract was adopted for the acetone extract (ACE) except that the extraction was done at room temperature $\left(28^{\circ} \mathrm{C}\right)$.

\section{Phytochemical analysis}

A small quantity of the powdered lichen was subjected to phytochemical tests using established standard procedures for the determination of alkaloids, tannins, saponins, glycosides, flavonoids, carbohydrates, fats and oil [13-15].

\section{Preparation of Virus Stock (Inoculum Build-up) \\ Yellow fever virus}

A yellow fever virus (vaccine) suspension (0.5 $\mathrm{ml}$ ) was used to infect a confluent monolayer of Vero cells in $250 \mathrm{ml}$ tissue culture flask and adsorbed for 1 hour to allow the viruses to adhere onto the cells. Non-adherent particles were washed off using 2\% RPMI (Rolswell Park Memorial Institute) medium and the infected cells overlaid with $20 \mathrm{ml}$ of $2 \%$ RPMI (maintenance medium) and incubated until full cytopathic effect was observed in 5 to 6 days. This was further repassed twice and the harvested virus stored at $20^{\circ} \mathrm{C}$ until used.

Poliomyelitis virus and IBDV (Gumboro virus)

A $0.2 \mathrm{ml}$ of stock suspensions each of infectious bursal disease virus (IBDV) and 
poliomyelitis virus was measured out using a micropipette and used to infect a confluent monolayer of Vero and $L_{20}$ cells respectively in a $50 \mathrm{ml}$ tissue culture flask and processed as described for yellow fever virus. Cytopathic effects were observed after 2 days and 6 days respectively for poliomyelitis and Gumboro virus (IBDV).

\section{Cytotoxicity tests of the extract}

A $1 \mathrm{~g}$ sample each of the three extracts (CPF, WTE and ACE) was weighed and suspended in 9 $\mathrm{ml}$ each of sterile distilled water (for CPF and WTE) and $9 \mathrm{ml}$ of $0.5 \%$ dimethylsulphoxide (DMSO) for ACE. The suspensions were agitated for 3 minutes to homogeneity using the vortex mixer type 16700 (Bamstead/Termolyne) before preserving at $4^{\circ} \mathrm{C}$. Serial dilutions of the extracts were then made to give $1 \%, 0.1 \%$ and $0.01 \%$ concentrations of the extracts in $2 \%$ RPMI. Thereafter, the growth medium (2\% RPMI) from the previously incubated confluent monolayers of Vero, $L_{20}$ and HEP-2 cells in 96-well plates were aspirated and $100 \mu \mathrm{l}$ aliquots of the diluted extracts seeded into the wells in quadruplicates. They were then overlaid with $100 \mu \mathrm{l}$ of $2 \%$ RPMI to bring to a final volume of $200 \mu \mathrm{l}$ in each well. Control wells were also set up in parallel with the inoculated wells. The plates were sealed and incubated at $37^{\circ} \mathrm{C}$ and observed daily for toxicity using an inverted microscope for 7 to 10 days before termination.

Titration of the viruses and determination of the $50 \%$ tissue culture infective dose $\left(T C I D_{50}\right)$

Stepwise 10 -fold (1/10) dilutions of the virus suspensions were made up to $10^{-8}$ in tissue culture tubes using $2 \%$ RPMI. The $100 \mu$ l aliquots of each dilution step were inoculated into the wells of a 96well tissue culture plate containing confluent Vero cells for yellow fever virus and Infectious Bursal Disease (Gumboro) virus and $L_{20}$ cells for poliomyelitis virus and $100 \mu \mathrm{l}$ of $2 \%$ RPMI bringing the overall volume to $200 \mu \mathrm{l}$. Each dilution step was seeded into four separate (quadruplicate) wells. The entire arrangements were incubated at $37^{\circ} \mathrm{C}$ and scored for cytopathic effect daily for 7 to 14 days before terminating the readings. The end point titres were calculated using the method of Kinchinton et al. [16].

\section{Determination of antiviral activity}

Various concentrations of the extracts were mixed in equal volumes $(100 \mu \mathrm{l})$ with $100 \mathrm{TCID}_{50}$ of the viruses, all in $2 \%$ RPMI. These were incubated for 1 hour before aliquots of $200 \mu$ of each mixture were used to infect a confluent monolayer of the respective cells in a 96-well tissue culture plate. The virus and cell controls were also set alongside these. They were later incubated at $37^{\circ} \mathrm{C}$ and scored daily using an inverted microscope for cytopathic effect for 10 to 14 days.

\section{Results}

The result of the phytochemical analysis (Table 1) shows that the lichen $P$. perlata contains flavonoids, saponins, tannins, glycosides (cardiac, cynogenetic but not the anthracene type), steroidal aglycone and carbohydrates but does not contain alkaloids.

Table 1. Result of Phytochemical Tests on Parmelia perlata.

\begin{tabular}{lc}
\hline Test & Inference \\
\hline Alkaloids & - \\
Cyanogenetic Glycosides & + \\
Cardiac Glycosides & + \\
Anthracene Glycosides & - \\
Steroidal Glycosides & + \\
Saponins & + \\
Tannins & + \\
Flavonoids & + \\
Proteins & + \\
Carbohydrates & + \\
Reducing sugar & + \\
\hline Key: + indicates presence of phytochemical secondary metabolite \\
- indicates absence of phytochemical secondary metabolite.
\end{tabular}

The results from phytochemical analysis have been observed to be consistent with findings in several lichen species except that the anthracene glycosides which constitute an important class of lichen substances [15] were absent; so also are the alkaloids. Other components found are abundant in several species of lichens [15, 17]. Glycosides are found commonly in lichens and include the galactose-arabitol glycoside (umbilicin) and the galactose-mannitol (peltigeroside) both of which abound in different lichen genera [18]. The 
result of the elemental analysis (Table 2) shows that zinc and lead are present in larger quantities ( 0.632 and $0.716 \mathrm{mg} / 100 \mathrm{~g}$ sample respectively) than cadmium, silver and chromium which were $0.038,0.216$ and $0.036 \mathrm{mg} / 100 \mathrm{~g}$ respectively while mercury, argon and cobalt were not present in detectable quantities. Low quantities of zinc and copper had earlier been reported in the lichen Ramalina farinacea [17] which was attributed to the natural habitat of the lichen (tree trunks) where these elements exist in minute quantities.

Table 2. Elemental Analysis of the Lichen, Parmelia perlata.

\begin{tabular}{cc}
\hline Element & Concentration in lichen $(\mathbf{m g} / \mathbf{1 0 0}$ of lichen) \\
\hline $\mathrm{Zn}$ & 0.632 \\
$\mathrm{~Pb}$ & 0.716 \\
$\mathrm{Cd}$ & 0.038 \\
$\mathrm{Ag}$ & 0.216 \\
$\mathrm{Cr}$ & 0.036 \\
$\mathrm{Hg}$ & $\mathrm{ND}$ \\
$\mathrm{Co}$ & $\mathrm{ND}$ \\
\hline
\end{tabular}

A summary of the cytotoxicity tests of the extracts on the cell lines (Hep-2, Vero and $L_{20}$ cells) is clearly depicted in Table 3.

Table 3. Toxicity of the extracts on Hep-2 Vero and $\mathrm{L} 20$ cells.

\begin{tabular}{|c|c|c|c|c|c|c|c|}
\hline & & \multicolumn{6}{|c|}{ Concentration of Extract $(\mu \mathrm{g} / \mathrm{ml})$} \\
\hline \multicolumn{2}{|c|}{ Cells Extracts } & $10^{5}$ & $10^{4}$ & $10^{3}$ & $10^{2}$ & 10 & 1 \\
\hline \multirow{3}{*}{ Hep-2 } & $\mathrm{CPF}$ & + & + & - & - & - & - \\
\hline & ACE & + & + & - & - & - & - \\
\hline & WTE & + & - & - & - & - & - \\
\hline \multirow{3}{*}{ Vero } & $\mathrm{CPF}$ & + & - & - & - & - & - \\
\hline & ACE & + & - & - & - & - & - \\
\hline & WTE & + & - & - & - & - & - \\
\hline \multirow{3}{*}{$\mathrm{L}_{20}$} & CPF & + & + & + & - & - & - \\
\hline & ACE & + & + & + & - & - & - \\
\hline & WTE & + & + & + & - & - & - \\
\hline
\end{tabular}

It is evident that the alkali extract (CPF) was toxic to Hep-2 cells up to $10^{4} \mu \mathrm{g} / \mathrm{ml}$, whereas toxicity was observed for Vero and $L_{20}$ cells at $10^{5}$ $\mu \mathrm{g} / \mathrm{ml}$ and $10^{3} \mu \mathrm{g} / \mathrm{ml}$ respectively. A similar trend was observed for the acetone extract (ACE). The water extract (WTE) exhibited little toxicity to both Hep-2 and Vero cell $\left(10^{5} \mu \mathrm{g} / \mathrm{ml}\right)$ but showed toxicity up to $10^{4} \mu \mathrm{g} / \mathrm{ml}$ in $L_{20}$ cells. Evaluation of the $\mathrm{TC}_{50}$ (Tables 4-6) further revealed that with the exception of $L_{20}$, all the extracts were generally not cytotoxic to the cells at concentrations below 500 $\mu \mathrm{g} / \mathrm{ml}$. Above $500 \mu \mathrm{g} / \mathrm{ml}$, cytotoxicity was observed in all the cell lines in the order: $\mathrm{L}_{20}>\mathrm{Hep} 2>$ Vero.

Table 4. Results of preliminary screening tests of the extracts on polio virus using $L_{20}$ cell lines

\begin{tabular}{cccc}
\hline Extract & $\mathrm{IC}_{50}(\mu \mathrm{g} / \mathrm{ml})$ & $\mathrm{TC}_{50}(\mu \mathrm{g} / \mathrm{ml})$ & S.I. \\
\hline CPF & 150 & 50 & 0.33 \\
ACE & $>10,000$ & 50 & $<0.005$ \\
WTE & 200 & 50 & 0.25
\end{tabular}

Key: $\mathrm{CPF}=$ crude polysaccharide fraction; $\mathrm{ACE}=\mathrm{Acetone}$ extract; WTE=Water extract; IC50=Concentration of the extract that inhibits viral infectivity (cytopathic effect) by $50 \%$; TC50=Concentration of extract that is cytotoxic to $50 \%$ of cells; S.I.=Selectivity Index $=$ TC50 IC50. The mean values of quadruplicate experiments are shown.

Table 5. Results of preliminary screening tests of the extracts on IBDV using Hep-2 cells

\begin{tabular}{cccc}
\hline Extract & $\mathrm{IC}_{50}(\mu \mathrm{g} / \mathrm{ml})$ & $\mathrm{TC}_{50}(\mu \mathrm{g} / \mathrm{ml})$ & S.I. \\
\hline CPF & $>10,000$ & 500 & $<0.05$ \\
ACE & $>10,000$ & 500 & $<0.05$ \\
WTE & $>1000$ & 5000 & $<5.00$
\end{tabular}

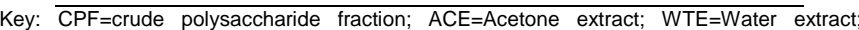
IC50=Concentration of the extract that inhibits viral infectivity (cytopathic effect) by $50 \%$; TC50 $=$ Concentration of extract that is cytotoxic to $50 \%$ of cells; S.I.=Selectivity Index = TC50/ IC50. The mean values of quadruplicate experiments are shown.

Table 6. Results of preliminary screening tests on yellow fever virus using vero cells

\begin{tabular}{cccc}
\hline Extract & $\mathrm{IC}_{50}(\mu \mathrm{g} / \mathrm{ml})$ & $\mathrm{TC}_{50}(\mu \mathrm{g} / \mathrm{ml})$ & S.I. \\
\hline CPF & 15 & 500 & 33.33 \\
ACE & $>10,00$ & 500 & $<0.50$ \\
WTE & 500 & 1000 & 2.00
\end{tabular}

Key: $\overline{C P F=c r u d e}$ polysaccharide fraction; $\mathrm{ACE}=$ Acetone extract; WTE=Water extract; IC50=Concentration of the extract that inhibits viral infectivity (cytopathic effect) by $50 \%$; TC50 $=$ Concentration of extract that is cytotoxic to $50 \%$ of cells; S.I.=Selectivity Index $=$ TC50/ IC50. The mean values of quadruplicate experiments are shown.

Table 7 shows the results of the virus titration and each result represents quadruplicate cultures. The $50 \%$ tissue culture infective dose $\left(T_{C 1 D_{50}}\right)$ shown against each virus was calculated according to the method of Kinchington et al. [16]. 
One emerging fact from the titration of the viruses/determination of the $\mathrm{TCID}_{50}$ is that the poliomyelitis virus had the highest titre followed by yellow fever and Gumboro viruses, which had similar titres (Table 7). These findings show the relative infectivity and the amount of virus particles per specimen.

Table 7. Results of the titration/determination of the $\mathrm{TCID}_{50}$ of the viruses.

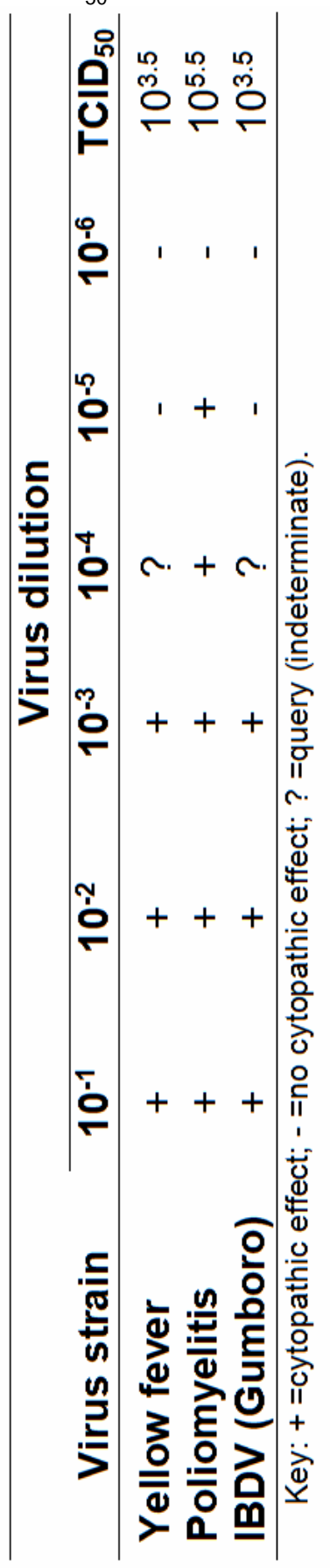

The results of the antiviral activity of the lichen extracts against poliomyelitis, IBDV and yellow fever viruses are presented in Tables 4 to 6 respectively. From the results, CPF prevented cytopathic effects caused by yellow fever virus on the Vero cells at concentrations 30-fold lower than its corresponding toxic concentration. This translates to a selectivity index of about 33.3. All the other extracts did not exert any noticeable activity against the test viruses at concentrations below the cytotoxic levels. The potent activity of CPF against the yellow fever virus $\left(\mathrm{IC}_{50}\right.$ of 15 $\mu \mathrm{g} / \mathrm{ml}$ ) is plausible, especially considering that a previous report shows a major limitation to the detection of antiviral effects of compounds in in vitro assays is the extremely low concentration of extracts tolerated by cells in the artificial systems [2].

\section{Discussion}

Anthraquinones, especially the polyphenolic and/or polysulphonate substituted types, have been shown to exhibit potent antiviral properties $[19,20]$. The lichen Parmelia perlata possesses glycosides other than the anthracene type, the parent precursor of the anthraquinones. Cohen et al. [9] also isolated anthraquinones, bianthrones and hyperacin derivatives from lichens whose antiviral activities were positively correlated with increasing substitution of chlorine in the anthraquinone structure. Therefore, it is plausible to suggest that similar manipulations can improve the antiviral effects of the nascent compounds in the crude lichen extracts. Plant polysaccharides have also been shown to exhibit potent antiviral activities, especially against enveloped viruses $[21,22]$. This corroborates the observed effect of CPF against the yellow fever virus, which is an enveloped RNA virus. One can conclude that the activity of CPF against yellow fever virus (an enveloped positive-sense RNA virus) as against poliomyelitis and IBDV (which are non-enveloped RNA viruses) is suggestive that the viral envelope could be the target for the antiviral action of the extract. However, an empirical conclusion to this effect could only be substantiated after further screening of CPF against several other enveloped viruses and after detailed molecular elucidation studies.

Varying the time of addition of the extracts to the incubated cell lines pre- or post-infection with 
the viruses did not have any marked effect on the efficacy of the extract.

In our previous study [10], we showed that out of about fifteen indigenous Nigerian medicinal plants screened for antiviral activity by a vectorbased assay technique, only extracts from the lichen Ramalina farinacea exhibited potent antiviral activity against HIV-1 (an enveloped RNA virus) and adenovirus type 5 (a non-enveloped DNA virus). Here we show that another tropical lichen from Nigeria also possesses antiviral activity, although against another viral family. Taken together, these studies demonstrate that lichens might represent a unique repertoire of novel antiviral phytomedicinal agents. In the current search for novel antiviral agents against current and emerging viral diseases, it might indeed be worthwhile to conduct pilot screening studies of diverse lichen species that are scattered around the globe.

\section{References}

1. De Clerq E (1993) Antiviral Agents: Characteristic activity spectrum depending on the molecular target with which they interact. Adv Drug Res 43: 1-55.

2. McCutcheon AR, Roberts JE, Ellis SM, Babiuk LA, Hancock REW, Towers GHN (1995) Antiviral screening of British Columbian medicinal plants. J Ethnopharm 49: $101-110$.

3. Cowan MM (1999) Plant products as antimicrobial agents. Clin Microbiol Rev 12: 564-582.

4. Jassim SA, Naji MA (2003) Novel antiviral agents: a medicinal plant perspective. J Appl Microbiol 95: 412427.

5. Esimone CO, Adikwu MU (2002) Susceptibility of some clinical isolates of Staphylococcus aureus to bioactive column fractions from the lichen Ramalina farinacea (L) Ach. Phytotherapy Research 16: 494-496.

6. Esimone CO, Adikwu MU (1999) Antimicrobial activity and cytotoxicity of Ramalina farinacea. Fitoterapia 70 : 428-431.

7. Esimone CO, Adikwu MU, Okonta JM (1998) Preliminary antimicrobial screening of the ethanolic extract from the lichen Usnea subfloridans (L). Journal of Pharmaceutical Research and Drug Development 3: 99-102.

8. Ranković B, Masic M, Sukdolak S (2007) The antimicrobial activity of substances derived from the lichens Physcia aipolia, Umbilicaria polyphylla, Parmelia caperata and Hypogymnia physodes. World Journal of Microbiology and Biotechnology DOI: 10.1007/s11274007-9580-7.

9. Cohen PA, Hudson JB, Towers GH (1996) Antiviral activities of anthraquinones, bianthrones and hypericin derivatives from lichens. Experientia 52: 180-183.

10. Esimone CO, Grunwald T, Wildner O, Nchinda G, Tippler $\mathrm{B}$, Proksch $\mathrm{P}$, Ueberla $\mathrm{K}$ (2005) In vitro Pharmacodynamic Evaluation of Antiviral Medicinal
Plants Using a Vector-based Assay Technique. J Appl Microbiol 99: 1346-1355.

11. Nicholson BE, Brightman FH (1966) The Oxford Textbook of Flowerless Plants. Oxford University Press, London. 297.

12. Esimone $\mathrm{CO}$, Omobowajo OR, Sowemimo AA, Proksch $P$ (2007) Single-Cycle Vector-Based Antiviral Screening Assays for High Throughput Evaluation of Potential AntiHIV Medicinal Plants: A Pilot Study on some Nigerian Herbs. Recent Progress in Medicinal Plant Research 19: 49-60.

13. Trease GE, Evans WC (2002) Pharmacognosy. 15th Ed. Saunders Publishers, London. pp. 42 - 393.

14. Harborne JB (1998) Phytochemical Methods: A guide to modern Techniques of plant Analysis. Chapman and Hall, New York, 2nd Ed.

15. Huneck S, Yoshimura $Y$ (1996) Identification of lichen substances. Springer, Berlin.

16. Kinchington D, Kangro $H$, Jeffries DJ (1995) Design and Testing of Antiviral Compounds, In: Medical Virology: A Practical Approach, Desselberger, U. (edn.) Oxford University Press, New York, $147-171$.

17. Esimone CO, Adikwu MU, Ebi GC, Anaga A, Njoku C (1999) Physicochemical evaluations and bioactive properties of column fractions from the lichen Ramalina farinacea (L) Ach. Bolletino Chimico Farmaceutico 138: 19-25.

18. Werner D (1992). Lichens and Geosiphon. In: Symbiosis of Plants and Microbes, Chapman and Hall: $271-298$.

19. Sydiskis RJ, Owen DG, Lohr JL, Rosle KHA, Blomster RN (1991) Inactivation of enveloped viruses by anthraquinones extracted from plants. Antimicrob. Agents and Chemother 35:2463-2466.

20. Schinazi RF, Chu CK, Baby JR, Oswald BJ, Saalman DL, Nasai M (1990) Anthraquinones as a new class of antiviral agents against Human Immunodeficiency virus. Antiviral Res. 13: 265-272.

21. Hosoya M, Balzarini J, Shigeta S, De Clercq E (1991) Differential inhibitory effects of sulphated polysaccharides and polymers on the replication of various myxoviruses and retroviruses, depending on the composition of the target amino acid sequences of the viral envelope glycoproteins. Antmicrob Agents Chemother 35: 25152520.

22. Premanathan $\mathrm{M}$, Kathiresan $\mathrm{K}$, Yamamoto $\mathrm{N}$, Nakashima $H$ (1999) In vitro anti-human immunodeficiency virus activity of polysaccharide from Rhizophora mucronata Poir. Bioscience, Biotechnology and Biochemistry 63: 1187-1191.

Corresponding Author: C.O. Esimone, Department of Pharmaceutics, University of Nigeria, Nsukka 410001, Enugu State, Nigeria, Tel: +234 80638584 70, e-mail: coesimone@yahoo.com.

Conflict of interest: No conflict of interest is declared. 